DOI: $10.15679 /$ bjwr.v4i2.57

\title{
CHARACTERISTICS OF LARGE UNGULATES HUNTING MANAGEMENT IN THE REPUBLIC OF SERBIA AT THE REGIONAL LEVEL
}

\author{
Lavadinović V. ${ }^{1}$, Popović $Z{ }^{2}$, Beuković D. ${ }^{3}$, Danilović M. ${ }^{1}$
}

Summary: Serbian hunting has suitable habitats, biodiversity potential and tradition. The breakup of SFR Yugoslavia severely affected it, causing devastation. In recent years, hunting has been recovering, but no proper insight has been provided about its current state. This paper is focused on the hunting management of autochthonous large ungulates as one of indicators of the quality of hunting in the country. Because traditional analyses are conducted at the national level, this research includes also regional comparison in order to identify potential differences. The results show that abundance of these game species at the national level is at an unsatisfactory level. Meanwhile, their management characteristics at the regional level are homogenous. It means that decision makers can implement the same measures to improve the game abundance and establish adequate management practices.

Key words: Serbia, game management, regions, deer, wild boar

\section{Introduction}

In Serbian medieval state hunting was appreciated among aristocracy, who used to organize large scale hunts modeled on Byzantines' customs. This tradition was stopped with Ottoman occupation, since it was forbidden for the enslaved indigenous people to hunt. After the Serbian liberation at the beginning of XIX century, and throughout whole the century, hunting was considered as a symbol of freedom and human rights, gathering people from all social layers. However, it is considered that organized hunting in Serbia started in 1896, since in this year the Hunting Association of Serbia was established (Lovački savez Srbije, 2004). Hunting and hunting clubs continued gradually to develop, becoming popular, except for the period of Balkan wars and WWI, until the WWII, which devastated the country. After the wars, the hunting sector started to recover faster than in the past and it reached its peak under Tito's rule in Socialistic Federative Republic of Yugoslavia. Proper game management was implemented across the country, new hunting grounds were established, the Yugoslavian Hunting Association became active, hunters were motivated to follow the code of conduct, universities started subjects related to hunting and industry developed programs to produce appropriate arms and ammunition for game keepers and professionals in the hunting sector (Stanković et al., 1992). Indicators of hunting development in this period are quality game trophies which were highly ranked on CIC lists and intensive cooperation of domestic hunting institutions with relevant international ones (Šelmić et al., 2001; Varićak, 2005). During this period, Serbia developed adequate professional resources to conduct proper hunting management in the country. Development of Serbian hunting sector was stopped during the ' 90 s, when the political and

\footnotetext{
${ }^{1}$ Prof. dr Danilović Milorad; Lavadinović Vukan, PhD; University of Belgrade, Faculty of Forestry, Belgrade, Serbia;

${ }^{2}$ Popović Zoran, PhD, professor; University of Belgrade, Faculty of Agriculture, Belgrade, Serbia;

${ }^{2}$ Beuković Dejan, PhD; University of Novi Sad, Faculty of Agriculture, Novi Sad, Serbia;

Corresponding author: Lavadinović Vukan, email: vukanlavadinovic@yahoo.com
} 
economical crises devastated the country, but it started to recover again after the democratic changes in 2000. Despite some improvements, the hunting sector is nowadays still below its potentials. At the same time, it is neglected by both the decision makers and the scientific community. But this did not stop the transition processes in the hunting sector, which resulted in new legislation and related changes. In such circumstances, the actual state of hunting and the hunting sector in Serbia is unknown, although the hunting grounds cover $99.86 \%$ of the country's total area (Vlada Republike Srbije, 2004; Popović et al., 2011). Therefore, this paper tends to provide deeper knowledge on Serbian hunting sector and to identify its characteristics, with special focus on main wild ungulate species managed in Serbian hunting grounds, such as Red Deer, Roe Deer and Wild Boar. In order to provide deeper knowledge, this paper goes beyond the traditional analyses of the hunting sector and includes not only the national but also the regional level.

\section{Material and Methods}

Data on the hunting grounds and game management were collected for 2012/13 hunting year, by the Directorate of Forestry on behalf of the Ministry of Agriculture and Environment as part of their regular activities. They disclosed the collected data for the purpose of this research. All these data origin from annual management plans for 2012/13 hunting year, as part of 10 year hunting ground management plans which are the obligatory official document for each hunting ground. The collected data were analyzed at the national and regional level. In total 272 out of 354 hunting grounds, which is $77 \%$ of all hunting grounds, were used to provide estimates at the national level. Findings obtained from the analyzed sample were used to calculate estimates for the whole country. These estimates are compared with the last comprehensive analysis of the hunting sector from 2000 (Šelmić i radna grupa LSS, 2001) in order to identify potential differences in game abundance.

Two statistical regions of Serbia (western Serbia and Šumadija; eastern and southern Serbia) were used in this research in order to identify and compare characteristics of hunting management at the regional level. These two regions were selected because they together form the region of central Serbia. For western Serbia and Šumadija, 75 hunting grounds were included in the research and 77 hunting grounds for eastern and southern Serbia (Figure 1).

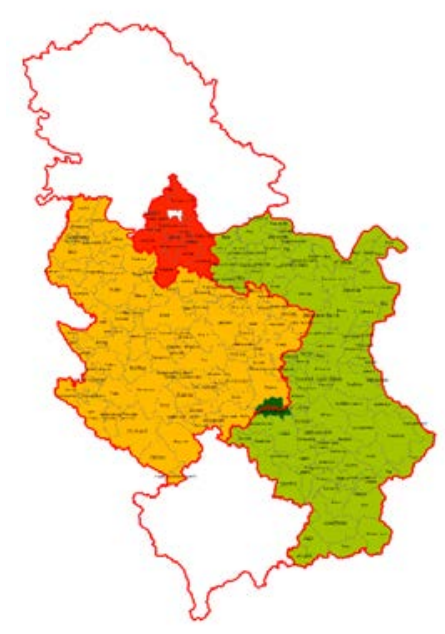

Figure 1. Hunting grounds in analyzed Serbian statistical regions - western Serbia and Šumadija and eastern and southern Serbia. Belgrade statistical region is marked with red color.

Although from geographical perspective some parts of Belgrade region belong to these two analyzed regions, they were excluded from this research because their hunting grounds are heavily influenced with human interference and differ from the rest of central Serbia. In order to compare 
game management in these two regions an utilization coefficient was developed, which is a ratio of population abundance and culling for each analyzed game species.

Data were analyzed in SPSS program. For testing the difference between various groups t-test for independent samples or One-Way ANOVA were used.

\section{Results and Discussion}

According to the obtained data, Serbian hunting grounds have suitable habitats for wild ungulate management, since these are mostly lowland-hilly regions covered with crops, grasslands and forest stands (Figure 2 and 3).

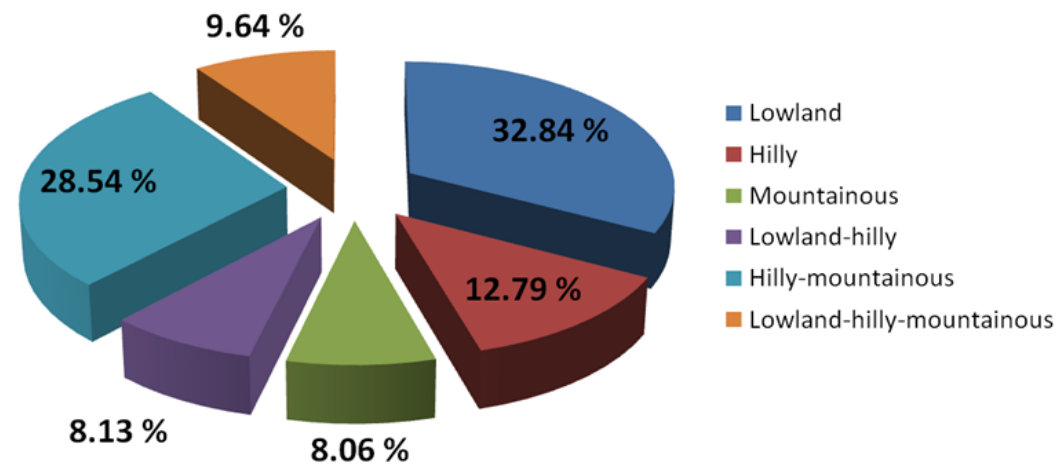

Figure 2. Distribution of hunting grounds per altitude category.

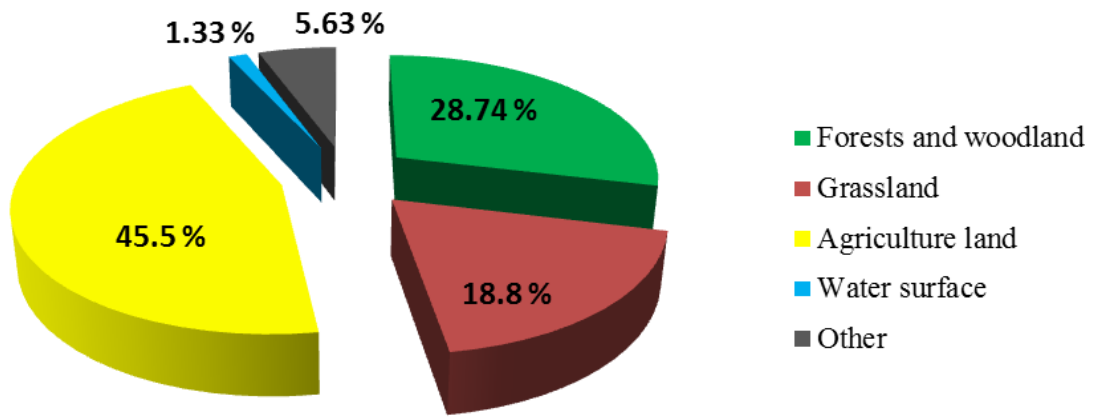

Figure 3. Share of land use in hunting grounds.

Distribution of wild ungulates per Serbian hunting grounds is not uniform, because Red Deer (Cervus elaphus L.) has been reported in approximately 13\% of the hunting grounds from the sample. In contrast with Red Deer, two other analyzed game species Roe Deer (Capreolus capreolus L.) and Wild Boar (Sus scrofa L.) are much more common in Serbia, being present in $90 \%$ and $75 \%$ of the hunting grounds, respectively. The population number of these species is variable per hunting grounds and goes from several individuals to several hundred. Similar case is with their abundance, which differs per hunting grounds.

The game distribution at the national level is in accordance with their total population number. Results from Table 1 show that Roe Deer is the most abundant large ungulate in Serbia, while Red Deer has the lowest population number. According to the same results, sex ratio of these game species is at the satisfactory level, because it is close to the optimal ratio of $1: 1$, which is used in 
Serbian game management (for Red Deer is 1:0.84 in favor of males; for Roe Deer it is 1:1.05 in favor of females; and for Wild Boar it is 1:1.04 in favor of females).

Table 1. Abundance of wild ungulate species in Serbia at the end of 2012/13 hunting year.

\begin{tabular}{|l|c|c|c|c|}
\hline \multicolumn{1}{|c|}{ Species } & Male & Female & Young & Total \\
\hline Red Deer & 3,258 & 2,738 & 1,199 & 7,195 \\
\hline Roe Deer & 38,641 & 40,622 & 19,294 & 98,557 \\
\hline Wild Boar & 6,557 & 6,841 & 9,366 & 22,764 \\
\hline
\end{tabular}

In order to identify possible changes in game management, the obtained data were compared with findings from the last comprehensive national survey and official statistical data. These findings are presented in Table 2 and 3.

Table 2. Comparison of large ungulate species abundance in Serbia for 1991., 2001. and 2013. (source: Šelmić i radna grupa LSS, 2001).

\begin{tabular}{|l|c|c|c|}
\hline \multirow{2}{*}{ Game species } & \multicolumn{2}{|c|}{ Abundance (individuals) } \\
\cline { 2 - 4 } & $\mathbf{1 9 9 1}$ & $\mathbf{2 0 0 1}$ & $\mathbf{2 0 1 3}$ \\
\hline Red Deer & 5,504 & 3,748 & 7,195 \\
\hline Roe Deer & 104,177 & 93,296 & 98,557 \\
\hline Wild Boar & 18,834 & 12,648 & 22,764 \\
\hline
\end{tabular}

Table 3. Abundance of large ungulates species in Serbia from 2005 to 2011. year (source: Statistical yearbook of Serbia, 2012).

\begin{tabular}{|l|c|c|c|c|c|}
\hline \multirow{2}{*}{ Game species } & \multicolumn{5}{|c|}{ Abundance (individuals) } \\
\cline { 2 - 6 } & $\mathbf{2 0 0 5}$ & $\mathbf{2 0 0 7}$ & $\mathbf{2 0 0 9}$ & $\mathbf{2 0 1 1}$ & $\mathbf{2 0 1 3}$ \\
\hline Red Deer & 4,869 & 4,589 & 6,296 & 4,801 & 7,195 \\
\hline Roe Deer & 106,000 & 112,000 & 111,000 & 117,000 & 98,557 \\
\hline Wild Boar & 17,215 & 17,436 & 17,475 & 17,865 & 22,764 \\
\hline
\end{tabular}

Comparison of the obtained findings with previous data identifies increase of the population number for Red Deer and Wild Boar. Since Red Deer in Serbia is mostly managed in fenced hunting areas, it is likely that better monitoring and protection resulted in the population increase. Nevertheless, Red Deer population in Serbia is still below its potentials. Slovakia, which is smaller in area, has 39,738 Red Deer individuals, which is more than 5 times more abundant (Green report, 2006). According to FACE (2002) and Zentralstelle Österreichischer Landesjagdverbände (2003), Austria shoots annually around 40,000 individuals, which is 5 times more than Serbia has in total. It can be assumed that Austrian population of Red Deer is at least 10 times higher than Serbian, although the areas of these countries are similar. Wild Boar is a species in expansion in Europe. Their number increases (Csányi, 1995; Bieberm and Ruf, 2005; Geisser and Reyer, 2006), which probably affects also Wild Boar population in Serbia. Despite positive changes in Red Deer and Wild Boar populations, Serbian hunting sector is still low-abundant with ungulate population in comparison with other European countries (Milner et al., 2006; Apollonio et al., 2010; Rivrud et al., 2013). The findings indicate that the number of Roe Deer in Serbia dropped, and that nowadays it is slightly higher than in 2001. The reasons why the number of Roe Deer decreased could be various. A possible explanation would be that overhunting, poaching and habitat loss have an important role (Šelmić i radna grupa LSS, 2001; Popović et al., 2014). The decrease of Roe Deer number in the country could have a negative impact on the hunting sector, due to the economic importance of this species (Popović et al., 2014). 
Besides the abundance, the data from the management plans were used also to calculate the scope of hunter's bag for the analyzed wild ungulates. During 2012/13 hunting season in the analyzed hunting grounds, 325 Red Deer adult males and 326 adult females were shot, which is a ratio of 1:1. Out of all shot individuals, both adult males and females are represented with 38\%, while calves are represented with $24 \%$. This shooting removed $13 \%$ of adult males, $15 \%$ of adult females and $23 \%$ of calves. These differences in the ratio of shooting are based on the unequal number of adult males and females. In Roe Deer population, hunting pressure on adult males is $10 \%$ out of their total number, $8 \%$ of all females are shot and $3 \%$ of all offspring.

Table 4. Hunting bags compared with the scope of culling in period 1988-1997 (source: Šelmić i radna grupa LSS,

2001).

\begin{tabular}{|l|c|c|c|c|c|}
\hline \multirow{2}{*}{ Game species } & \multicolumn{5}{c|}{ Hunting bag } \\
\cline { 2 - 6 } & $\mathbf{1 9 8 8}$ & $\mathbf{1 9 9 2}$ & $\mathbf{1 9 9 5}$ & $\mathbf{1 9 9 7}$ & $\mathbf{2 0 1 3}$ \\
\hline Red Deer & 1,205 & 921 & 706 & 499 & 1,125 \\
\hline Roe Deer & 9,253 & 7,700 & 4,298 & 3,667 & 7,011 \\
\hline Wild Boar & 4,109 & 5,285 & 2,522 & 2,642 & 8,177 \\
\hline
\end{tabular}

Table 5. Comparison of estimates on the scope of hunters' bag at the national level for even-toed ungulates and hunters' bag in period 2005-2011 (source: Statistical yearbook of Serbia, 2012).

\begin{tabular}{|l|c|c|c|c|c|}
\hline \multirow{2}{*}{$\begin{array}{c}\text { Game } \\
\text { species }\end{array}$} & \multicolumn{5}{|c|}{ Hunters' bag } \\
\cline { 2 - 6 } & $\mathbf{2 0 0 5}$ & $\mathbf{2 0 0 7}$ & $\mathbf{2 0 0 9}$ & $\mathbf{2 0 1 1}$ & $\mathbf{2 0 1 3}$ \\
\hline Red Deer & 884 & 615 & 757 & 767 & 1,125 \\
\hline Roe Deer & 5,000 & 7,000 & 8,000 & 8,000 & 7,011 \\
\hline Wild Boar & 3,918 & 5,276 & 5,811 & 4,962 & 8,177 \\
\hline
\end{tabular}

Results indicate that $50 \%$ of the total hunters' bag are adult males, $42 \%$ are females, while cubs account for $8 \%$ of the hunter's bag . According to the analyzed data for Wild Boar, the hunting pressure accounted for $25 \%$ of adult males, $23 \%$ of adult females and $54 \%$ of yearlings. Out of the total shooting quota, adult males are represented with $20 \%$, adult females with $19 \%$, while yearlings are represented with 61\%. These findings are not in accordance with literature sources (Drenić 1995; Novaković, 1999; Novaković, 2003). Besides, the obtained findings were compared with data on culling from other source in Table 4 and 5. According to these comparisons, it appears that the scope of culling in 2012/13 hunting year is higher than in the previous period, which could be an indicator of improved hunting management, but it is still low in comparison with other European countries. For example, in 2005 Slovakia, on the smaller area, shot 12,723 Red Deer individuals, 17,170 Roe Deer individuals and 21,804 Wild Boar individuals (Lavadinović, 2007).

Previous results and calculations were used to provide more information about hunting management of wild ungulates at the national level. As mentioned previously, this research goes beyond it and also includes research on hunting management at the regional level. For this purpose, a utilization coefficient (Uc) was developed, which is a ratio between estimated game abundance at the beginning of a hunting season and realized shooting quota during the same season. Both variables were collected for 2012/13 hunting year. This utilization coefficient (Uc) was compared with the one-factor analysis of variance for game species per statistical regions of central Serbia (Table 6). The differences between regions were registered using Scheffe's test. The one-way ANOVA did not identify any statistically significant differences in the Uc per statistical regions for the analyzed game species (Table 7). The results indicate that there are no differences in hunting management between these two regions for all analyzed wild ungulate species. 
Table 6. Descriptive statistics for the utilization coefficient for analyzed game species.

\begin{tabular}{|l|c|c|c|c|}
\hline \multicolumn{1}{|c|}{ Region } & Game species & $\mathbf{N}$ & Mean & Std. Deviation \\
\hline Eastern and southern Serbia & \multirow{2}{*}{ Red Deer } & 7 & 0.0863 & 0.11432 \\
\cline { 1 - 3 } & & 12 & 0.0642 & 0.08964 \\
\hline Western Serbia and Šumadija & \multirow{2}{*}{ Roe Deer } & 63 & 0.5161 & 0.24082 \\
\cline { 4 - 5 } & & 70 & 0.4831 & 0.27226 \\
\hline Western and southern Serbia & \multirow{2}{*}{ Wild Boar } & 59 & 0.2637 & 0.33648 \\
\hline Eastern Serbia and Šumadija & & 62 & 0.2484 & 0.22086 \\
\hline Western Serbia and Šumadija & & & \\
\cline { 3 - 5 }
\end{tabular}

Table 7. Findings of Scheffe's test of the utilization coefficients for Red Deer per statistical regions (statistically significant differences are in bold).

\begin{tabular}{|c|c|c|c|c|c|}
\hline (I) Region & $\begin{array}{c}\text { Game } \\
\text { species }\end{array}$ & (J) Region & Mean Difference (I-J) & Std. Error & Sig. \\
\hline Eastern and southern Serbia & Red Deer & $\begin{array}{c}\text { Western Serbia and } \\
\text { Šumadija }\end{array}$ & 0.02211 & 0.04108 & 0.961 \\
\hline Eastern and southern Serbia & Roe Deer & $\begin{array}{c}\text { Western Serbia and } \\
\text { Šumadija }\end{array}$ & 0.03297 & 0.04212 & 0.893 \\
\hline Eastern and southern Serbia & Wild Boar & $\begin{array}{c}\text { Western Serbia and } \\
\text { Šumadija }\end{array}$ & 0.01539 & 0.05896 & 0.995 \\
\hline
\end{tabular}

\section{Conclusion}

According to the obtained analyses, Serbia has suitable habitats for wild ungulate management, but it does not meet its potentials. Despite improvements in the number of Red Deer and Wild Boar, game abundance is still low in comparison with the other European countries, while the findings indicate that the number of Roe Deer is in decrease. This issue is even more threatened with increased scope of culling, which appears not to be in accordance with game abundance. Although the data indicate that populations of wild ungulates have the required sex ratio, the structure of culling is not adequate and not in coherence with literature recommendations. Therefore, it can be concluded that the state of wild ungulates in Serbia, despite some improvements, is not at the satisfactory level.

Analysis of regional game management characteristics shows a uniform situation for all three large ungulate species in central Serbia, which means that the decision makers can implement the same policy instruments in both analyzed regions in order to increase the game abundance and conduct proper management in the future.

This research has several limitations which should be taken in consideration. The analysis includes only the hunting grounds which provided data to the Directorate of Forestry. The rest of the hunting grounds did not provide data due to unknown reasons. It is likely that some of them were not able to do so, because they are newly established due to changes which have occurred in the sector. Therefore, the data are biased from this perspective. All data were collected from hunting grounds management plans, which are official documents. Nevertheless, there are claims that they are not always a reliable source, but it was the only possibility to conduct the survey at the national level and we had to deal with this risk. Also, it should be taken in consideration that estimates at the national level do not include data from the autonomous provinces of Kosovo and Metohija. However, we believe that this research provides proper insight in Serbian game management and that these findings are solid.

\section{References}

1. Apollonio, M., Andersen, R., and R. Putman. 2010. European Ungulates and their Management in the 21st Century. Cambridge University Press, United Kingdom. 
2. Bieberm C., and T. Ruf. 2005. Population dynamics in Wild Boar Sus scrofa: ecology, elasticity of growth rate and implications for the management of pulsed resource consumers. Journal of Applied Ecology 42 (6): 1203-1213.

3. Csányi, S. 1995. Wild boar population dynamics and management in Hungary. Journal of Mountain Ecology 3: 222-225.

4. Drenić, M. 1995.Srneća divljač. Drugo izdanje, Demetra - Knjaževac, Srbija.

5. FACE (The European Federation of Associations for Hunting and Conservation). 2002. Hunting in Austria. [online] Available at: http://www.face.eu/sites/default/files/ austria_en_0.pdf [Accessed 6 August 2015].

6. Geisser, H., and H.U. Reyer. 2006. The influence of food and temperature on population density of Wild Boar Sus scrofa in the Thurgau (Switzerland). Journal of Zoology 267 (1):89-96.

7. Green report. 2006. Report on Forestry in the Slovak Republic 2006. Ministry of Agriculture of the Slovak Republic, Bratislava, National Forest Centre - Forest Research Institute Zvolen.

8. Lavadinović, V. 2007. Uporedna analiza lovstva Slovačke i Srbije. Diplomski rad. Šumarski fakultet Univerziteta u Beogradu.

9. Lovački savez Srbije. 2004. Istorijat - Prvih 100 godina. [online] Available at: http://www.ecolss.com/prvih_sto_godina.htm [Accessed 5 November 2012].

10. Milner, J.M., Bonenfant, C., Mysterud, A., Gaillard, J-M., Csányi, S., and N.C. Stenseth. 2006. Temporal and spatial development of red deer harvesting in Europe: biological and cultural factors. Journal of Applied Ecology 43 (4): $721-734$.

11. Novaković, V. 1999. Jelen (Cervus elaphus L.). Ministarstvo Poljoprivrede, šumarstva i vodoprivrede Republike Srbije. Srbija.

12. Novaković, V. 2003. Divlja svinja (Sus scrofa L.). Lovački Savez Srbije. Srbija.

13. Popović, Z., Đorđević, N., Živković, D., Beuković, M., Beuković, D., i M. Đorđević. 2011. Brojnost i stepen korišćenja populacije zeca i fazana u lovištima Lovačkog saveza Srbije. Međunarodno naučno-stručno savjetovanje agronoma Republike Srpske "Prirodni resursi u funkciji razvoja poljoprivrede i ruralnog područja". Trebinje, Republika Srpska, 22-25 March 2011. Trebinje, Republika Srpska.

14. Popović, Z., Živković, D., and V. Lavadinović. 2014. Microeconomic analysis of game population management in hunting grounds. In: $3^{\text {rd }}$ International Symposium on hunting - Moderns aspects of sustainable management of game population. Zemun-Belgrade, Serbia, 26-28. September 2014. Faculty of Agriculture, University of Belgrade, Serbia.

15. Rivrud, I.M., Sonkoly, K., Lehoczki, R., Csányi, S., Storvik, G.O., and A. Mysterud. 2013. Hunter selection and long-term trend (1881-2008) of red deer trophy sizes in Hungary. Journal of Applied Ecology 50 (1): 168-180.

16. Stanković, S., et al. 1992. Velika ilustrovana enciklopedija lovstva - Druga knjiga. Drugo dopunjeno izdanje. Građevinska knjiga, Beograd; Dnevnik, Novi Sad.

17. Statistical yearbook of Serbia. 2012. Statistical yearbook 2012. Statistical office of the Republic of Serbia.

18. Šelmić, V., Gačić, D., and A., Ćeranić. 2001. Hunting and hunting industry. Yugoslav Survey 3: 103-132.

19. Šelmić, V. i radna grupa LSS. 2001. Program razvoja lovstva Srbije 2001-2010. Lovački Savez Srbije, Beograd.

20. Varićak. V. 2005. Ocenjivanje lovačkih trofeja: prema formulama CIC-a: divljač Srbije. Lovačka biblioteka "Sv. Evstatije", Lovački Savez Srbije.

21. Vlada Republike Srbije. 2004. Činjenice o Srbiji - Osnovni podaci. [on line] Available at: http://www.srbija.gov.rs/pages/article.php?id=36 [Accessed 22 July 2012].

22. Zentralstelle Österreichischer Landesjagdverbände. 2003. DAS WILD- Statistik der wichtigsten jagdbaren Wildarten. [online] Available at: http://www.ljv.at/jagd_wild.htm [Accessed 09 April 2014].

\section{Acknowledgement}

Ministry of education, science and technological development of the Republic of Serbia which financed these investigations within the project TR-31009.

Received: 21.05.2017.

Accepted: 23.12.2017.

Lavadinović V., Popović Z. , Beuković D., Danilović M. (2017). Characteristics of large ungulates hunting management in Republic of Serbia at the regional level, Balkan Journal of Wildlife Research, 4(2), pp.11-17. 